\title{
Within the States' Jurisdiction: Metropolitan, Northeast Bancorp, and the Equal Protection Clause
}

\author{
David W. Haller
}

The equal protection clause of the Fourteenth Amendment provides that "[n]o State shall . . . deny to any person within its jurisdiction the equal protection of the laws." Although the jurisdictional element of this clause qualifies the states' obligation to provide equal protection, it has been largely ignored and ill defined. The jurisdictional requirement says in effect that the limit on state sovereignty imposed by the equal protection clause shall go "thus far and no farther." By passing over this threshold determination of whether an entity is entitled to equal protection and immediately applying a rational basis test, courts have decided some cases incorrectly and others without sufficient analytic rigor. Assuming, as one must, that the words "within its jurisdiction" have some meaning, ${ }^{2}$ it is constitutionally proper to discern that meaning ${ }^{3}$ and plumb its depth.

The purpose of this Note, therefore, is to define the jurisdictional extent of the states' obligation to provide equal protection. ${ }^{4}$ It focuses for the

1. U.S. Const. amend. XIV, $\S 1$ (emphasis added). To have a right to the equal protection of a state's laws, therefore, an entity must not only be a "person" but must also, within the meaning of the equal protection clause, be within that state's "jurisdiction."

2. See Marbury v. Madison, 5 U.S. (1 Cranch) 137, 174 (1803) ("It cannot be presumed that any clause in the constitution is intended to be without effect; and, therefore, such a construction is inadmissable, unless the words require it.").

3. The legislative history of the equal protection clause lends little assistance in clothing this phrase with meaning. The drafting committee, which kept its deliberations secret, did not leave a statement of purpose. The floor debates concentrated on the terms for readmission of the southern states and spent little time discussing the equal protection clause. What discussion did transpire was almost entirely race-related. See, e.g., CoNG. Globe, 39th Cong., 1st Sess. 2764 (1866) (remarks of Sen. Howard). See generally Fairman, Does the Fourteenth Amendment Incorporate the Bill of Rights?: The Original Understanding, 2 STaN. L. REv. 5 (1949); Frank \& Munro, The Original Understanding of "Equal Protection of the Laws," 50 Colum. L. Rev. 131 (1950).

Some commentators have argued that the Framers did not even intend corporations to be "persons" within the meaning of the equal protection clause. See Boudin, Truth and Fiction About the Fourteenth Amendment, 16 N.Y.U. L.Q. REv. 19 (1938); Graham, The "Conspiracy Theory" of the Fourteenth Amendment (pts. 1 \& 2), 47 YAL.E L.J. 371, 385-87 (1938), 48 YALE L.J. 171 (1938). If the personhood of corporations is suspect, the proposition that corporations can obtain a right to the equal protection of a state's laws by putting themselves within that state's jurisdiction without its consent is even more questionable. For purposes of this Note, the personhood question is considered closed by subsequent case law. See Southern Ry. v. Greene, 216 U.S. 400, 412-13 (1910); Pembina Consol. Silver Mining \& Milling Co. v. Pennsylvania, 125 U.S. 181, 189 (1888).

4. The Supreme Court has never attempted to define in a comprehensive manner the precise scope 
most part on the jurisdictional status of out-of-state corporations. ${ }^{5}$ In practical terms, its importance is most obvious in areas such as banking and insurance in which Congress has lifted dormant commerce clause restraints on the states' economic regulatory authority. ${ }^{6}$

Section I of this Note distills from the case law two factors that inform the Court's jurisprudence on the extent of the duty imposed by the equal protection clause. It argues that a foreign corporation is generally entitled to the equal protection of a state's laws whenever it is subject to the jurisdiction of that state's courts, but cannot invoke the equal protection clause in order to enter a state to do business without that state's consent or to

of a state's jurisdictional obligation to provide the equal protection of its laws. In addition, because the Court has resolved the jurisdictional question in individual cases on an ad hoc basis, it is nearly impossible to abstract from these decisions an integrated analytic model. Moreover, judicial opinions that address this issue either explicitly or by implication are rare. Courts generally dispose of cases that present the jurisdictional issue on other grounds, reaching privileges and immunities or commerce clause claims first. See infra note 5 . Even when the equal protection claim is squarely presented, the courts often bypass the question of the jurisdictional extent to which a state must provide equal protection by deciding that the classification used by the state is in any event reasonable. See B. CurRIE, SELECTED EsSays ON THE Conflicts of Laws 536 (1963).

5. Equal protection claims are likely to arise in this context because the privileges and immunities clause, U.S. CoNST. art. IV, $\S 2$, under which parallel claims might be presented, provides no protection to corporations. Corporations have long been held not to be "citizens" within the meaning of article IV, § 2. Hemphill v. Orloff, 277 U.S. 537, 548-50 (1928); Paul v. Virginia, 75 U.S. (8 Wall.) 168, 177-82 (1868); Bank of Augusta v. Earle, 38 U.S. (13 Pet.) 519, $586-87$ (1839).

A natural person who is a citizen of one of the states is protected by the privileges and immunities clause and is therefore, in practical terms, unaffected by the jurisdictional qualification of the equal protection clause. Moreover, a citizen outside a state's jurisdiction possesses an unqualified right to interstate travel, Jones v. Helms, 452 U.S. 412, 417-19 (1981), and can place herself within that state's jurisdiction free of state interference.

Theoretically, an out-of-state alien, like a foreign corporation not admitted to do business in a state, may be unable to invoke the equal protection of that state's laws. However, as this Note argues, a state could discriminate against or among aliens without a rational basis, if at all, only with respect to requirements for entering the state. See infra text accompanying notes 25-32. Furthermore, with respect to entrance requirements and alienage generally, the federal government's interest in, and power to regulate, immigration preempts individual states from discriminating against out-of-state aliens. For the argument that the supremacy clause, not equal protection analysis, is the proper mode for analyzing the problem of the equal treatment of aliens, see Note, The Equal Treatment of Aliens: Preemption or Equal Protection? 31 Stan. L. Rev. 1069 (1979); Note, State Burdens on Resident Aliens: A New Preemption Analysis, 89 Yale L.J. 940 (1980); see also C. BlaCk, Structure AND RELATIONSHIP IN CoNSTITUTIONAL. LAW 64 (1969) ("[T]he national power over aliens as such is paramount, and ... the states may not in general take any action against them as aliens."); Perry, Modern Equal Protection: A Conceptualization and Appraisal, 79 CoLuM. L. REv. 1023, 1060-65 (1979).

6. Equal protection claims to do business in a state can often be framed as claims under the commerce clause. When Congress allows the states to regulate interstate economic activity, however, the equal protection question becomes dispositive. See infra note 59. For example, the Webb-Kenyon Act, ch. 90, 37 Stat. 699 (1913) (codified at 27 U.S.C. \$ 122 (1982)), and the Twenty-First Amendment allow the states to regulate the importation of intoxicating liquors notwithstanding the commerce clause. See Carter v. Virginia, 321 U.S. 131, 137 (1944). Similar considerations may also apply with respect to the Federal Power Act. See, e.g., First Iowa Hydro-Elec. Coop. v. FPC, 328 U.S. 152 (1946) (\$ 9(b) of Federal Power Act permits states to regulate appropriation, diversion, and use of water for power purposes). On a broad level, this Note demonstrates that Congress may delegate its economic regulatory power to the states without fearing that the resulting scheme of regulation might be vitiated by private corporations invoking the equal protection clause. 
expand the scope of the business it has been authorized to carry on there. Section II establishes that the rational basis test and an alternative threshold jurisdictional test of an entity's right to equal protection often, but not always, generate similar outcomes. Section III, however, argues that it is analytically improper to ignore the jurisdictional test and that rational basis analysis, standing alone, is incapable of justifying a subset of cases upholding statutes that discriminate either against or among foreign corporations. ${ }^{7}$ Section IV, by application of the jurisdictional test, gives a more adequate explanation than the Court itself has offered of the different results reached in two recent Supreme Court cases, Metropolitan Life Insurance Co. v. Ward ${ }^{8}$ and Northeast Bancorp v. Board of Governors of the Federal Reserve System. ${ }^{9}$

\section{The Jurisdictional Extent of the Right to Equal Protection}

The case law on the scope of the state's jurisdiction for purposes of the equal protection clause is sparse and not entirely consistent. In two cases, the Supreme Court, after reciting a litany of relevant facts, flatly stated that a particular foreign corporation was within the state's jurisdiction for the purposes of that case. ${ }^{10}$ However, in another case with almost identi-

7. Because this Note concludes that a state may withhold the equal protection of its laws only in certain narrowly defined circumstances, it is generally consonant with a broad application of the equal protection clause. See Plyler v. Doe, 457 U.S. 202, 214 (1982).

8. 470 U.S. 869 (1985).

9. 472 U.S. 159 (1985).

10. In Southern Railway v. Greene, 216 U.S. 400 (1910) (additional franchise tax levied only on corporations incorporated out of state but doing business in state unconstitutional denial of equal protection), a majority of the Court held that,

[i]n the present case the plaintiff is taxed because it is doing business within the State of Alabama. The averments . . . show it has acquired a large amount of railroad property by authority of and in compliance with the laws of the State; that it is subject to the jurisdiction of the courts of the State; that it has paid taxes upon its property, and also upon its franchises within the State; in short, that it came into the State in compliance with its laws, and at the time of the imposition of the tax in question had been for many years carrying on business therein under the laws of the State. We can have no doubt that a corporation thus situated is within the jurisdiction of the State.

Id. at 413 .

In Hughes v. Alexandria Scrap Corp., 426 U.S. 794 (1976), because the Court ultimately upheld a statute favoring in-state processors of abandoned automobile hulks for purposes of a bounty program on the basis of the rationality of the classification it drew, it did not have to reach the jurisidictional question. Where, as in Hughes, the Court upholds a discriminatory state statute, it is often unclear which element of equal protection analysis is dispositive-whether the classification employed is reasonable or whether the complainant is outside the jurisdiction of the state, or both. The Court in Hughes, however, was faced with an argument on the jurisdictional point and answered it thus: Appellee . . . paid a fee to become licensed under Maryland law, maintains an office in Maryland as required by Maryland regulation, and has been found by the District Court to be subject to the jurisdiction of Maryland courts under the State's "long arm" statute. . . . [I]t is "within [Maryland's] jurisdiction" at least for the purposes of this licensing and bounty program.

Id. at 811 n.21 (brackets in original). 
cal facts, the Court found the corporation involved to be outside the state's jurisdiction. ${ }^{11}$ In yet another case, the Court noted the absence of these pertinent facts and found the corporation to be outside the state's jurisdiction. ${ }^{12}$ Finally, in two other cases, the Court did not make an explicit jurisdictional determination, but nonetheless implicitly found the corporation to be within the state's jurisdiction by striking down a discriminatory statute on the ground that it was not rationally related to a legitimate state interest. ${ }^{13}$

Despite its lack of development, this case law provides a framework upon which one can construct a coherent definition of the extent of the state's obligation to provide equal protection. Two factors relevant to whether a corporation is within the jurisdiction of a state are recurrent: (1) whether the corporation is reached by the laws, or is subject to compulsory process by the courts, of that state, and (2) whether the corporation has assets or representatives within the territory of the state, or has in any case been legally admitted to do business there. ${ }^{14}$

11. See Philadelphia Fire Ass'n v. New York, 119 U.S. 110 (1886) (foreign corporation contesting discriminatory state taxes held outside state's jurisdiction). This result is contrary to that reached in Southern Railway v. Greene, and yet the corporation involved was

doing business in [New York] by the latter's consent, evidenced by the official certificate given by her insurance department in conformity with her laws, and liable, precisely as domestic corporations are, to be brought into her courts, through service of process upon its duly appointed attorney or agent, in reference to any business transacted or liability incurred by it there ....

Id. at 122 (Harlan, J., dissenting).

12. See Blake v. McClung, 172 U.S. 239 (1898) (statute that subordinated claims in insolvency proceedings of foreign corporations to claims of creditors residing in state did not constitute denial of equal protection). In Blake, the Court interpreted the phrase "within its jurisdiction" as follows:

Without attempting to state what is the full import of the words, . . . it is safe to say that a corporation not created by Tennessee, nor doing business there under conditions that subjected it to process issuing from the courts of Tennessee at the instance of suitors, is not, under the above clause of the Fourteenth Amendment, within the jurisdiction of that State.

Id. at 261. In addition, the Court stated that a foreign corporation did not come within the jurisdiction of Tennessee merely by presenting its claim in one of the state's courts. Id.

13. See Hanover Fire Ins. Co. v. Harding, 272 U.S. 494 (1926) (discriminatory tax on out-ofstate insurance companies unconstitutional). Distinguishing Southern Railway $v$. Greene, the Court stated that

the complainant has from year to year secured renewal of its license in the State of Illinois, and has through many years past built up a large good will in the State of Illinois, and has associated with it a large number of agents in the various counties of the State, whose connection with it has resulted in a large and profitable business to the complainant, and that it has large numbers of records containing information respecting its policy holders [in the state].

Id. at 508-09; Metropolitan Life Ins. Co. v. Ward, 470 U.S. 869 (1985) (imposition of discriminatory taxes on out-of-state insurance companies held unconstitutional), see infra text accompanying notes 55-67.

14. The Court has never said that one or both of these elements constitute the definitive test of whether an entity is entitled to equal protection. Rather, the Court has usually noted facts that are implicitly relevant to one of the factors, and then, in the next breath, held that a corporation so situated was or was not within the state's jurisdiction. See cases cited supra notes 10-13.

This Note uses the concepts these factors represent to frame a coherent definition of the scope of the state's jurisdiction for purposes of the equal protection clause. Because of developments in accepted notions of judicial jurisdiction, these factors may point in different directions. Rather than adopt a test 


\section{A. The Personal Jurisdiction Standard}

The first factor, whether the corporation is reached by the laws of a state, borrows the concept of personal jurisdiction to delineate the scope of the state's jurisdiction for purposes of equal protection. It is unclear, however, how changing conceptions of personal jurisdiction should affect the weight accorded to this factor. International Shoe Co. v. Washington ${ }^{15}$ and state long-arm statutes have, subsequent to the passage of the Fourteenth Amendment, greatly extended the territorial range within which a state, through its courts, may assert its jurisdiction to adjudicate disputes.

The first factor, being concerned with personal jurisdiction, implies that persons should have the benefit of equal protection whenever they can be reached by a state's courts. ${ }^{18}$ If that reach is subsequently extended-because of the introduction of the concept of minimum contacts or for any other reason-persons newly subject to the jurisdiction of those courts, and therefore to the coercive power or the state, ought to be similarly protected. ${ }^{17}$ The reach of personal jurisdiction, however, may have expanded to such an extent that the first factor for determining the applicability of the equal protection clause completely eclipses the second. And the second factor represents strong and valid historical concerns that cannot be ignored.

\section{B. A Territorial Limit on the Standard}

The tenor of the second factor is territorial. ${ }^{18}$ It turns on whether certain objects or persons are physically within the territory of the state, or

that would balance conflicting factors in individual cases, this Note argues that the tension between these factors defines in a general way both the extent and the limit of the state's duty to provide equal protection.

15. 326 U.S. 310 (1945) (Delaware corporation had sufficient contacts with Washington to make it reasonable under due process clause to require corporation to defend suit brought there to recover unpaid unemployment compensation contributions).

16. Of course, if entities are entitled to the equal protection of a state's laws whenever legitimate contacts with the state subject them to that state's laws, it should not matter that the court applying that law is a court of a different state.

17. See Plyler v. Doe, 457 U.S. 202, 211-12 (1982) ("[W]e have recognized that both [the due process and equal protection clauses] were fashioned . . . to reach every exercise of state authority."); id. at 214 (equal protection clause intended to extend "to all upon whom the State would impose the obligations of its laws"); Oregon v. Mitchell, 400 U.S. 112, 251 (1970) (Brennan, White \& Marshall, JJ., concurring in part and dissenting in part) ("It is clear that the language of the Fourteenth Amendment . . . applies on its face to all assertions of state power, however made.").

18. The territorial theme is very strong in decisions discussing the jurisdictional requirement of the equal protection clause. See, e.g., Plyler v. Doe, 457 U.S. at 215 ("Use of the phrase "within its jurisdiction' thus does not detract from, but rather confirms, the understanding that the protection of the Fourteenth Amendment extends to anyone, citizen or stranger, who is subject to the laws of a State, and reaches into every corner of a State's territory."); id. at $211 \mathrm{n} .10$ (noting the "predominantly geographic sense" in which similar provision of citizenship clause has been construed); Missouri ex rel. Gaines v. Canada, 305 U.S. 337, 350 (1938) ("TT]he obligation of the State to give the protection of equal laws . . . is imposed by the Constitution upon the States severally as governmental 
alternatively, whether certain activities have been carried on there. ${ }^{19}$ It is informed by a theory of constructive "presence" rather than "minimum contacts." Historically, a Colorado corporation, for example, did not "exist" outside of Colorado. ${ }^{20}$ Corporations were legal entities sustained solely by the power of the state that created them, and that power extended no farther than the state's boundaries.

In cases that held that a corporation did not "exist" outside its state of incorporation, however, the Court was primarily concerned that foreign corporations not be allowed to do business in another state without that state's consent. ${ }^{21}$ According to these decisions, a state has the right to ex-

entities, - each responsible for its own laws establishing the rights and duties of persons within its borders."); Yick Wo v. Hopkins, 118 U.S. 356, 369 (1886) (equal protection clause applies "to all persons within the territorial jurisdiction"); see also United States v. Wong Kim Ark, 169 U.S. 649, 678-95 (1898) (holding that jurisdictional provision of the equal protection clause is similar in meaning to comparable provision of citizenship clause and maintaining that phrase "subject to its jurisdiction" in citizenship clause is term of art intended to encompass all persons within territorial borders of the United States except diplomats who, although "present" in United States, remain subject to their own sovereign).

However, a definition of the state's jurisdictional duty to provide equal protection couched purely in territorial terms would be problematic. Because corporations are by nature legal abstractions, whether a corporation is "present" within the territory of a state is not always self-evident. In addition, since International Shoe and the advent of state long-arm statutes, a territorial test would permit a state to deny equal protection to many corporations that are nonetheless subject to the jurisdiction of its courts. For this reason, this Note argues that the territorial nature of the second factor is in tension with and modifies a more general personal jurisdiction standard of the scope of the state's duty to provide equal protection. Territorial concerns are valid in this context; they are not dispositive.

19. Brainerd Currie dismisses out of hand the territorial approach as "almost certainly too narrow." B. CuRrIE, supra note 4 , at 530 . The mainstay of his argument is that such an approach would exclude all corporations incorporated outside the state from the equal protection of the laws-even those licensed to do business and in fact doing business, in the state. That result clearly would be contrary to the Court's decisions in Power Manufacturing Co. v. Saunders, 274 U.S. 490 (1927), Hanover Fire Insurance Co. v. Harding, 272 U.S. 494 (1926), and Southern Railway v. Greene, 216 U.S. 400 (1910). A territorial test of the extent of the state's jurisdiction for purposes of the equal protection clause would exclude foreign corporations from its protection, he contends, because Bank of Augusta v. Earie, 38 U.S. (13 Pet.) 519, 588 (1839), unquestionably held that corporations have no existence outside the state of their creation. Therefore, under a territorial test, they can never invoke the equal protection clause in a foreign state.

Curric's analysis of the territorial test is itself almost certainly too narrow. In Pembina Consolidated Silver Mining \& Milling Co. v. Pennsylvania, 125 U.S. 181 (1888), the Court addressed the question of the extent to which a foreign corporation "exists" within a state for purposes of equal protection. The Court initially stated that "[t]he plaintiff in error [a Colorado corporation] is not a corporation within the jurisdiction of Pennsylvania." 125 U.S. at 189. However, in examining the question further it found that "the office it hires is within such jurisdiction . . . . It would then have the equal protection of the law so far as it had anything within the jurisdiction of the State, and the [Fourteenth] amendment requires nothing more." Id. at 189.

20. Pembina Consol. Silver Mining \& Milling Co. v. Pennsylvania, 125 U.S. 181 (1888); Paul v. Virginia, 75 U.S. (8 Wall.) 168 (1868); Bank of Augusta v. Earle, 38 U.S. (13 Pet.) at 588. For a discussion of Pembina, see supra note 19.

21. The same concern motivates the Court's jurisprudence with respect to corporations and the privileges and immunities clause. The practical implications of the argument made in this Note depend on the fact that corporations are not "citizens" within the meaning of the privileges and immunities clause. See supra note 5. For this reason, the policies and purposes behind excluding corporations from the protections of the privileges and immunites clause should be indicative of the policies and purposes behind limiting the reach of equal protection.

The term "citizens" in the privileges and immunities clause is narrower than the term "persons" in 
clude foreign corporations from doing business within its borders. The mere incorporation of a company in one state, therefore, is not enough to give that corporation a right to existence in other states.

But a state may, if it wishes, "recognize" the existence of a foreign corporation within its territory. ${ }^{22}$ Traditionally a state recognizes the existence of a foreign corporation by granting it the right to do business in the state. Once recognized, or licensed to enter a state to do business, a foreign corporation "exists" within the state's territory to an extent sufficient to trigger the guarantee of equal protection-at least with respect to the business it has been allowed to pursue there. Its existence is restricted and of a different character than the existence of domestic corporations, but it is sufficient to merit equal protection. ${ }^{23}$

The right of a foreign corporation, legally doing business in a state, to the equal protection of that state's laws is not controversial. Such a corporation is-by virtue of both of the factors mentioned above-clearly

the equal protection clause. See Cong. Globe, 39th Cong., 1st Sess. 2766 (1866) (remarks of Sen. Howard) "'The last two clauses of the first section of the amendment disable a State from depriving not merely a citizen of the United States, but any person . . . [of] the equal protection of the laws of the State." (emphasis added)). Senator Howard noted that the term citizen was used two other times in the Constitution: that document requires that both the President and Senators be "citizens." Id. at 2765. He went on to say that in these provisions and in the privileges and immunities clause, "[s]uch persons were, therefore, citizens of the United States as were born in the country or were made such by naturalization ....."Id. Thus one difference between "citizens" and "persons" is that "citizens" must be natural persons, while the term "persons" includes entities such as corporations that depend for their legal existence on the state.

The case law that denies corporations the status of "citizenship" for purposes of the privileges and immunities clause demonstrates a similar concern for state consent and territoriality. In Bank of Augusta $v$. Earle, for example, the Court concluded that if a corporate entity wants the same privileges with respect to the right to contract as citizens of a state, it must also accept the same duty-that is, full and not limited liability. Id. at 586-87. Since the power to confer limited liability rests with the state, entities clothed with it by another state cannot, without the host state's consent, do business in that form. The Court in Hemphill v. Orloff, 277 U.S. 537 (1928), expressed similar concerns. A corporation, the Court said, in which the owners are exempted from personal liability, cannot conduct business in a state without that state's consent. Id. at 548-50.

A corporation seeking to do business in a state does not merely seek the ordinary privileges and immunities of the citizens of that state; it wants more than that. It wants to do business there with the special privilege of limited liability. Corporations, therefore, are not "citizens" within the meaning of the privileges and immunites clause for the same reason that they are not within the state's jurisdiction for purposes of the equal protection clause-because a state must consent to the doing of business in its territory by an entity clothed with special privileges.

22. See, e.g., Pembina, 125 U.S. at 186 ("Therefore, the recognition of [the foreign corporation's] existence in Pennsylvania . . . was a matter dependent on the will of the State.").

23. See Hughes v. Alexandria Scrap Corp., 426 U.S. 794, 810 n.21 (1976); Southern Ry. v. Greene, 216 U.S. 400, 413 (1910); Philadelphia Fire Ass'n v. New York, 119 U.S. 110, 122 (1886) (Harlan, J., dissenting); see also Wheeling Steel Corp. v. Glander, 337 U.S. 562 (1949) (ad valorem tax on notes and accounts receivable of foreign corporations violates equal protection clause); WHYY v. Borough of Glassboro, 393 U.S. 117 (1968) (per curiam) (denial of tax-exempt status to nonprofit corporation solely because of its foreign incorporation violates equal protection clause). These last two cases both held that, although a state may impose restrictions on the right of foreign corporations to enter its territory in order to do business there, "once it has permitted them to enter, "the adopted corporations are entitled to equal protection with the state's own corporate progeny . . . " WHYY, 393 U.S. at 119 (quoting Wheeling Steel, 337 U.S. at 571). 
within the state's jurisdiction for purposes of the equal protection clause. The real difficulty lies in assessing the status of a corporation that is within the jurisdictional reach of a state's courts or legislature, but has not been admitted to do business there.

\section{The Line Between the Rule and the Exception}

The first factor stands for the proposition that corporations subject to the legislative jurisdiction of a state, or the compulsory jurisdiction of a state's courts, are generally entitled to invoke the equal protection of that state's laws. The second factor, however, suggests several limitations on this principle. ${ }^{24}$ It suggests, first of all, that the state retains a sufficient degree of sovereignty ${ }^{25}$ to deny a foreign corporation the right to do business within its borders, and to limit the scope of the business pursued by foreign corporations it chooses to admit. ${ }^{28}$ It also suggests that, within the meaning of the equal protection clause, a corporation may be within the state's jurisdiction for some purposes but not for others. ${ }^{27} \mathrm{~A}$ corporation is within the state's jurisdiction only with respect to assets or agents it has in the state, and with respect to claims arising out of activities that it legitimately ${ }^{28}$ carries on there. ${ }^{28}$

24. Plyler v. Doe, 457 U.S. 202 (1982), recognizes both the personal jurisdiction and territorial concerns of the jurisdictional element of the equal protection clause: "the phrase "within its jurisdiction' was intended in a broad sense to offer the guarantee of equal protection to all within a State's boundaries, and to all upon whom the State would impose the obligation of its laws." Id. at 214; see supra notes 17-18.

25. In this respect, a corporation's jurisdictional right to equal protection is consensual-that is, dependent not only upon the activities of the corporation but also upon the will of the state. Cf. $\mathrm{P}$. Schuck \& R. SMITH, CrTIzenship Without CoNSENT 84-89 (1985) (arguing that citizenship clause of the Fourteenth Amendment which requires that United States confer citizenship on "[a]ll persons born or naturalized in the United States and subject to the jurisdiction thereof," U.S. CoNST. amend. XIV, $\S 1$ (emphasis added), evidences Framers' intent that citizenship remain consensual matter between government and subject).

26. By allowing states to refuse to extend the equal protection of their laws only in these two circumstances, the argument presented in this Note avoids the problem inherent in permitting states to set conditions on the admission of particular corporations-namely, where does it end? See Western \& S. Life Ins. Co. v. Board of Equalization, 451 U.S. 648, 658 (1981) ("[I]f the State's right to withold the privilege [of doing business in the state] is absolute, then no one has the right to challenge the terms under which the State chooses to exercise that right."). A state may completely deny entry to a foreign corporation, or it may limit the scope of the business it will be allowed to pursue in the state, but that is all. After that, the corporation is entitled to protection equal to that enjoyed by the "state's own corporate progeny." Wheeling, 337 U.S. at 571.

27. See Hughes v. Alexandria Scrap Corp., 426 U.S. at $811 \mathrm{n} .21$ ("Appellee . . . is "within [Maryland's] jurisdiction' at least for the purposes of this licensing and bounty program." (brackets in original)); Philadelphia Fire Ass'n v. New York, 119 U.S. 110, 120 (1886) (Harlan J., dissenting) ("II]t is equally clear that a corporation of one State doing business in another State by her consent, is to be deemed, at least in respect to that business, a 'person' within the jurisdiction of the latter State, in the meaning of the Fourteenth Amendment.").

28. Legitimate activities include both those for which the corporation is licensed and other legal activities that transpire in, or are connected with, the state. A foreign corporation that has not been admitted to do business in a state is nonetheless within the state's jurisdiction for claims arising from other legitimate contacts with that state. It has, for example, a right to equal treatment in litigation, 
By making the commitment of citizenship, residency, or incorporation, a person-natural or corporate-acquires both the duties and benefits of that status, one of which is the benefit of the equal protection of the state's laws. ${ }^{30} \mathrm{~A}$ citizen of a state or a corporation legally incorporated there may be held answerable by the courts of that state upon causes of action that do not arise out of contacts with the state. ${ }^{31}$ Similarly, a citizen of a state or a company incorporated there may be within the jurisdiction of the state within the meaning of the equal protection clause for all purposes, and not just with respect to causes of action arising from its contacts with the state.

A corporation, however, does not formally exist in a state if it has not been recognized or authorized to do business there. A foreign corporation, having foregone the opportunity to incorporate locally and not possessing a right to recognition or existence in a foreign state, does not have the right unilaterally to enter a state to do business or to invoke equal protection for that purpose. ${ }^{32}$ Corporations may be "persons," but outside their

(1) against debtors residing in the state, (2) involving property located in the state, (3) involving a tort committed by or upon one of its officers there, and (4) with respect to a contract legitimately entered into there. A foreign corporation legally doing business in a state, on the other hand, has a right to equal treatment in all actions arising out of the business it conducts there as well as in actions arising from other legitimate contacts with the state.

29. This jurisdictional limit on a state's duty to provide equal protection reflects a similar limit on the right of a state's courts to assert personal jurisdiction. See Hanson v. Denckla, 357 U.S. 235, 251 (1958) ("The cause of action in this case is not one that arises out of an act done or transaction consummated in the forum State."); see also American Eutectic Welding Alloys Sales Co. v. Dytron Alloys Corp., 439 F.2d 428, 432 (2d Cir. 1971) ("There remains the requirement that plaintiffs" cause of action be one 'arising from' that activity . . ..").

30. Domestic corporations, therefore, must be accorded equal protection for all purposes-including expanding the scope of the business they conduct both inside and outside of the state. They should be treated as "citizens" of the state that created them. See infra note 31.

For a discussion of the similar treatment accorded by the Court to the privileges and immunites clause-requiring that an entity that wishes to be treated as a citizen of a state accept both the benefits and duties of citizenship-see supra note 21 .

31. "[T]here have been instances in which the continuous corporate operations within a state were thought so substantial and of such a nature as to justify suit against it on causes of action arising from dealings entirely distinct from those activities." International Shoe Co. v. Washington, 326 U.S. 310, 318 (1945). By incorporating in a state a corporation may be held to have consented to the bringing of actions there. See Kent v. Universal Film Mfg. Co., 200 A.D. 539, 193 N.Y.S. 838 (1922); 19 C.J.S. Corporations \$ 1294 (1939); see also R. Weintraub, Commentary on the Conflict of Laws 192 (3d ed. 1986) ("Incorporation in the forum is an additional basis for jurisdiction over corporations ... ."). Citizenship and residence have traditionally been accepted as bases of general jurisdiction over natural persons. See Milliken v. Meyer, 311 U.S. 457 (1940) (domicile in state sufficient to support jurisdiction over absent defendant); Blackmer v. United States, 284 U.S. 421 (1932) (United States citizen subject to service of process while residing in France). For a discussion of contacts "unrelated" to a specific controversy supporting the exercise of "general" jurisdiction, see generally Brilmayer, How Contacts Count: Due Process Limitations on State Court Jurisdiction, 1980 SuP. Cr. REv. 77, 80-88.

32. States can set the terms and conditions upon which they will give their consent to the local incorporation of a company, and a company unwilling or unable to accept these conditions cannot demand an unqualified right to equal protection. See Prudential Ins. Co. v. Cheek, 259 U.S. 530, 536 (1922) ("[T]he right to conduct business in the form of a corporation . . . is not a natural or fundamental right. It is a creature of the law; and a State in authorizing its own corporations or those of 
state of incorporation they do not "exist"-are not "within [another state's] jurisdiction"-unless that state permits them to be.

"Jurisdiction" and "existence" are in this sense consensual. They are dependent not only on the activity of the corporation but also, at least to a degree, upon the will of the state. ${ }^{33}$ The state, of course, cannot have it both ways. It may not let a corporation into the state to do business and yet deny it equal protection. Nevertheless, it retains the residual sovereignty to stop a corporation at its borders and prohibit it from doing business there without offending the strictures of the equal protection clause.

To be sure, a foreign corporation not admitted to do business in the state may be able to develop contacts sufficient to support the exercise of personal jurisdiction by a court of that state for the adjudication of a particular claim. With respect to claims arising out of these contacts it is entitled to equal protection. But that corporation is not by virtue of these limited contacts within the jurisdiction of the state for any and all claims that it might assert.

In summary, a foreign corporation possesses a general right to equal protection of the laws of a state with the following exceptions: the corporation cannot rely on the equal protection clause in order to do business in a state without that state's consent; it cannot assert a right to equal protection in order to expand the scope of the business it is licensed to conduct there; nor can it claim it is entitled to equal protection with respect to matters not arising from its legitimate, authorized contacts with the state.

\section{The Limited INTERdependence OF JURISDICTION AND RATIONALITY}

Properly understood, equal protection analysis has two components: a jurisdictional requirement, and, disregarding varying degrees of scrutiny, a rational relation test. A corporation protesting state action under the equal protection clause, therefore, must show both that it is within the state's jurisdiction for purposes of the equal protection clause and that the action it is challenging is not rationally related to furthering a legitimate state interest. If a court finds a corporation to be within the state's jurisdiction, it must then proceed to determine whether the challenged statute is rationally based, and that determination becomes dispositive-just as it would be were the jurisdictional inquiry ignored entirely. Ignoring the

other States to carry on business . . . within its borders may qualify the privilege by imposing such conditions and duties as reasonably may be deemed expedient ... . ."); Doggrell v. Great S. Box Co., 206 F.2d 671, 677 (6th Cir. 1953) ("The state of incorporation may adopt such requirements as to corporate organization as it may deem appropriate; provided the requirements do not conflict with the Federal Constitution."); 18 C.J.S. Corporations § 26 (1939).

33. See supra note 25 . 
jurisdictional inquiry, therefore, in cases where that inquiry would have resulted in finding that the corporation was within the state's jurisdiction is, in terms of the outcome ultimately reached, of little consequence. ${ }^{34}$ Similarly, in cases where a court upholds a statute as rationally related to a legitimate state interest, a corporation's equal protection claim fails even if the corporation is within the state's jurisdiction.

Whatever the dialectic between the two components of equal protection analysis, when the discrimination at issue is not against foreign corporations trying to enter a state to do business or against those attempting to expand the scope of the business they already carry on there, the jurisdictional and rational basis inquiries often track each other and reach similar results. Discrimination against a foreign corporation outside the jurisdiction of the state is very often discrimination with a rational basis. Conversely, the fact that a foreign/domestic classification is irrational often, although not always, implies that the entities discriminated against are within the state's jurisdiction.

When a corporation is without assets or agents in a state or is not doing business there, any discrimination it might suffer is generally rationally based. Because it is not doing business in the state-authorized or otherwise-such a corporation has a right to equal protection only with respect to its sporadic contacts with the state. Thus, the two elements of equal protection analysis-the jurisdictional and rational basis components-are often closely entwined. This relationship explains much of the confusion in determining in certain cases which of these elements was dispositive.

The connection between these two elements is best illustrated by a typical case. In Board of Education v. Illinois, ${ }^{35}$ the Court held that the classification in an Illinois statute exempting only in-state charitable and religious corporations from provisions of the inheritance tax laws was rationally based. The Court determined that the Kentucky corporation involved was differently situated than in-state corporations because its charter required its funds to be expended solely in the state of Kentucky, and because it did not maintain an office in Illinois or "engage in educational or religious work therein." 38

The Kentucky nonprofit corporation, having had no "contacts" with Illinois, much less having done business there, was outside that state's jurisdiction for purposes of the equal protection clause for similar reasons. The corporation had no connection with the state-besides a general in-

34. Of course, one does not know the result of the jurisdictional inquiry until one makes it. Because of the possibility that the corporation was outside the state's jurisdiction, it is only ex post-that is, after the jurisdictional inquiry is made and answered in the affirmative-that it is clear in cases of this sort that the result reached was the right one.

35. 203 U.S. 553 (1906).

36. Id. at 558 . 
terest in Illinois residents' being able to contribute to its cause taxfree-with respect to which it could claim the equal protection of Illinois' laws. Thus, the requirement that a complainant be within the state's jurisdiction is sometimes used as a proxy for saying that a state can legitimately discriminate against those whom it is rational to treat differently. ${ }^{37}$

Where a corporation is outside the state's jurisdiction and faces a rationally based statute, passing over the jurisdictional inquiry is without consequence not because the answer to that inquiry requires the rational basis test to be reached anyway, but because the jurisdictional and rational basis tests, as alternative tests, give the same answer. In cases of this sort, relying on the jurisdictional requirement would have substantial clarificatory power because of its simplicity. ${ }^{38}$ The jurisdictional inquiry requires only a determination of whether a corporation has been admitted or licensed to do business in a particular state. Rational relation analysis, on the other hand, involves a complicated and often confusing scrutiny of the legitimacy of state purposes and the rationality of statutory classifications.

In summary, the jurisdictional and rational basis tests often generate similar outcomes. The jurisdictional inquiry, however, is not only constitutionally required but is often substantially clearer and simpler than rational relation analysis in justifying the same outcome.

37. In Power Manufacturing Co. v. Saunders, 274 U.S. 490 (1927), the Court unwittingly combined the issues of jurisdiction and rationality:

Here the separate classification of foreign corporations is in respect of the venue or place of bringing transitory actions. The statutes mean foreign corporations doing business within the State by her permission, and therefore having a fixed place of business therein and a resident agent on whom process may be served. We speak only of them. So far as their situation has any pertinence to the venue of transitory actions it is not distinguishable from that of domestic corporations and individuals.

Id. at 494. Similarly, in WHYY v. Borough of Glassboro, 393 U.S. 117 (1968) (per curiam), the Court combined the two components of equal protection analysis. The Pennsylvania nonprofit corporation in WHYY operated and had facilities in New Jersey, had New Jersey's permission to enter the state, and nearly $30 \%$ of its audience resided there. The Court was unable to find any distinction between the "appellant and domestic nonprofit corporations which would justify the inequality of treatment." Id. From these same circumstances, the Court determined that WHYY was within the jurisdiction of the State of New Jersey and entitled to the equal protection of its laws. Had WHYY been outside the state's jurisdiction, Board of Education $v$. Illinois provides sufficient proof that a distinction on which to base a rational classification would easily have been found.

38. The jurisdictional test, of course, is not only more easily applied than the rational basis test but is also more rigid. In addition, the jurisdictional question does not decide all cases. It is dispositive of equal protection claims only when the claimant is outside the state's "jurisdiction." When the claimant is inside the state's jurisdiction-that is, when the corporation passes the jurisdictional test-the statute must still be subjected to rational relation analysis and may be upheld under this test in any event. 


\section{Actual State Purposes and Judicial Gandor}

The jurisdictional test is not only characterized by clarity and simplicity but is absolutely integral to deciding cases that uphold the states' right in certain circumstances to discriminate against foreign corporations. Cases of this sort, where a foreign corporation is outside the state's jurisdiction but is attacking an irrational statute, are of two types: they involve either discrimination against a foreign corporation trying to expand the scope of the business it is authorized to carry on in the state, or discrimination against a foreign corporation trying to enter the state to do business. This Section begins by arguing that discrimination against foreign corporations within a state's jurisdiction merely because they are foreign is almost never rationally based ${ }^{39} \mathrm{~A}$ state may nonetheless discriminate against foreign corporations when, for purposes of the equal protection clause, they are outside its jurisdiction. Because the Court has failed to invoke the jurisdictional requirement in cases where it has sanctioned discrimination against foreign corporations, it has erroneously relied on the rational basis test in distinguishing between corporations that are in reality similarly situated. Decisions of this sort, therefore, are without adequate foundation.

Courts use rational relation analysis to ensure that the classification ${ }^{40}$ employed by a particular statute furthers some legitimate state purpose. ${ }^{41}$ "Rationality review," observes Professor Sunstein, "makes sense only if it is accompanied by a willingness to close off the universe of permissible statutory purposes-to limit the reasons for which one person can be

39. It is rational to discriminate against foreign corporations in cases of the sort discussed in Section II, where the foreign corporation discriminated against is not within the state's jurisdiction because it is not doing, and is not attempting to do, business in the state. The present Section focuses on cases in which the jurisdictional and rational basis tests give different answers-that is, cases in which the classification employed by a statute is irrational but the foreign corporation invoking the equal protection clause is outside the state's jurisdicition.

40. Unfortunately, courts and commentators have occasionally employed the word "means", rather than using the term "classification," in phrasing the proposition that under the equal protection clause a statute's "means" must be rationally related to its purpose. The essence of equal protection doctrine-where fundamental rights are not involved-is rational classification, not reasonable means. It is concerned that a classification " be reasonable, not arbitrary, and must rest upon some ground of difference having a fair and substantial relation to the object of the legislation, so that all persons similarly circumstanced shall be treated alike." " Colgate v. Harvey, 296 U.S. 404, 423 (1935) (quoting F.S. Royster Guano Co. v. Virginia, 253 U.S. 412, 415 (1920)). Thus, the equal protection clause would not be concerned with whether a state chooses to raise revenue by a property tax or by a sales tax (as long as these are both legitimate); rather, it is concerned that, whatever the tax, "persons" similarly situated are taxed at equal rates.

41. See Trimble v. Gordon, 430 U.S. 762, 766 (1977); see also Allied Stores of Ohio v. Bowers, 358 U.S. 522, 527 (1959) ("The rule often has been stated to be that the classification 'must rest upon some ground of difference having a fair and substantial relation to the object of the legislation." " (quoting Royster Guano, 253 U.S. at 415)). 
treated differently from another, and to require that the applicable reasons be stated at an intermediate level of generality."

Almost any statutory classification benefiting a group is rationally related to furthering the interests of that group. If merely helping the favored class were a legitimate state purpose, the equal protection clause would be without force and meaning. ${ }^{43}$ Blatant local favoritism, like blatant racial preferences, cannot be a legitimate state purpose. Legislation must promote some public value."4 Under a general statutory scheme that discriminates between foreign and domestic corporations, therefore, it should be obvious that at least one purpose is conclusively invalid: favoring the domestic business of local corporations solely because they are local. ${ }^{45} \mathrm{~A}$ state that wishes to aid its locally incorporated businesses must have some other reason for doing so.

Following Sunstein again, because certain purposes are impermissible, rationality review "can be understood as a means of ensuring that unconstitutional motivations do not in fact account for statutory classifications."18 To determine, therefore, whether statutes that discriminate against foreign corporations are rationally related to a legitimate state interest requires an inquiry into purposes and motivations. Rationality itself, as almost all statutes are rationally related to doing what they in fact do, is not a test at all.

This Note will employ something similar to the rational basis test as a logical tool to examine the probable purposes or motives behind statutes that discriminate against out-of-state corporations. In this manner, it will demonstrate that states generally discriminate against out-of-state corpora-

42. Sunstein, Public Values, Private Interests, and the Equal Protection Clause, 1982 SuP. CT. REv. 127, 130-31 (emphasis added).

43. See id. at 130; Note, Legislative Purpose, Rationality, and Equal Protection, 82 YAl. L.J. 123 (1972); Note, Taxing Out-of-State Corporations After Western \& Southern: An Equal Protection Analysis, 34 STAN. L. REv. 877, 887 (1982) [hereinafter Note, Taxing Out-of-State Corporations].

44. Sunstein, supra note 42 , at 131 ("[T]he Court requires differential treatment to be justified by reference to some public value. A justification that rests on the intrinsic value of treating one person differently from another is prohibited.").

45. Minnesota v. Clover Leaf Creamery Co., 449 U.S. 456, 471 (1981) ("If a state law purporting to promote [legitimate] purposes is in reality 'simple economic protectionism,' we have applied a "virtually per se rule of invalidity." "quoting City of Philadelphia v. New Jersey, 437 U,S. 617, 624 (1978))); United States Dep't of Agric. v. Moreno, 413 U.S. 528, 534 (1973) ("[A] bare congressional desire to harm a politically unpopular group cannot constitute a legitimate governmental interest."); Wheeling Steel Corp. v. Glander, 337 U.S. 562, 572 (1949) (holding unconstitutional discrimination based solely on "different residence of the owner"); Power Mfg. Co. v. Saunders, 274 U.S. 490, 493-94 (1927); see also Sunstein, supra note 42, at 134 ("[O]ut-of-bounds justifications have a common characteristic. When the government operates to benefit $A$ and burden $B$, it may do so only if it is prepared to justify its decision by reference to a public value. $A$ bare decision to prefer $A$ to $B$, because the comparative disadvantage is intrinsically desirable, is not sufficient."); Sunstein, Naked Preferences and the Constitution, 84 Colum. L. Rev. 1689 (1984).

46. Sunstein, supra note 42, at 131 (emphasis added); see also Ely, Legislative and Administrative Motivation in Constitutional Law, 79 Y ALE L.J. 1205 (1970). 
tions with the sole purpose of favoring in-state corporations. This Note assumes that if a statutory classification does not or is logically unlikely to further the particular purpose articulated for a statute, it is unlikely that that purpose was the legislature's actual purpose in enacting the statute. This Section, therefore, attempts to "flush out," at a general level, impermissible ends, by examining the "fit" between a statutory classification that discriminates against out-of-state corporations and permissible ends. ${ }^{17}$

Various state interests that are ostensibly advanced by a statutory scheme treating locally incorporated businesses favorably are in fact unlikely to be furthered by such a scheme. ${ }^{48}$ One purpose, the benefit of

47. Rational relation analysis, as a means of uncovering illegitimate state purposes, is meaningless if the line between a state's purpose in enacting a statute and the means it uses to achieve that purpose is manipulable. See Note, Taxing Out-of-State Corporations, supra note 43, at 891-93. In Western \& Southern Life Insurance Co. v. Board of Equalization, 451 U.S. 648 (1981), for example, the Court upheld a statute that imposed "a retaliatory tax on out-of-state insurers doing business in California, when the insurer's State of incorporation imposes higher taxes on California insurers doing business in that State than California would otherwise impose on that State's insurer's doing business in California." Id. at 650 (footnote omitted). The statutory classification itself reveals that it is probably not the state's purpose nakedly to prefer domestic over foreign corporations with reference to business done in the state. No domestic insurers were disadvantaged by the statute, but not all foreign insurers were either. The statute's purpose, as agreed upon by the majority, the state, and the dissenters, was "to promote the interstate business of domestic insurers by deterring other States from enacting discriminatory or excessive taxes." Id. at 668.

The second part of this phrase-"by deterring other States from enacting discriminatory or excessive taxes"-may at first look more like a means than a purpose. A statute's purpose, however, must encompass those steps absolutely necessary to effect it. These necessary means-different from the classification-would then be required, as part of the statutory purpose, to be legitimate.

California did not deny that it meant to promote the interstate business of domestic insurers by influencing the legislatures of other states to enact favorable legislation. The dissenters found the second part of this purpose objectionable. Justice Stevens stated that a "coercive motivation is not an acceptable justification for California's discriminatory treatment of nonresidents." Id. at 675 .

Assuming that Justice Stevens was able to persuade his colleagues that it was illegitimate for a state so to influence the legislatures of its sister states, it would be mere subterfuge for a state to say that its purpose in enacting a statute like that challenged in Western Es Southern was not to promote the interstate business of domestic insurers by influencing other state legislatures, but was only to promote the interstate business of domestic insurers. The necessary "means" by which the classification employed by California effects its purpose is inseparable from that purpose. It is, in fact, part of the purpose itself. California's intention was to coerce other states into lowering their taxes and thereby to help the interstate business of California insurers. The statute does not aid domestic insurers unless it coerces other state's legislatures. Western E Southern, then, should be read as having held that the entire statutory purpose presented by the state-to promote the interstate business of domestic insurers by deterring other states from enacting discriminatory or excessive taxes-was legitimate, and not that aiding the interstate business of domestic insurers alone was legitimate.

Although the Court did not directly address the jurisdictional issue in Western $\mathcal{E}$ Southern, that case is consistent with the interpretation given the jurisdictional requirement in this Note. Western $\mathcal{E}^{\circ}$ Southern held that "whatever the extent of a State's authority to exclude foreign corporations from doing business within its boundaries, that authority does not justify imposition of more onerous . . . burdens on foreign corporations than those imposed on domestic corporations, unless the discrimination . . . bears a rational relation to a legitimate State purpose." Id. at 667-68. A corporation being taxed by a state is necessarily within that state's jurisdiction at least for the purposes of the business being taxed. It is therefore entitled to the equal protection of that state's laws with respect to that business, and any discriminatory taxing scheme must be justified, if at all, as rationally related to a legitimate state purpose.

48. For a discussion of the legitimacy of various state purposes under the equal protection clause, the commerce clause, and the privileges and immunities clause, see generally Ely, Choice of Law and 
increased employment, for instance, although it may be weakly correlated to the domestic/foreign distinction, depends more on the assets invested in a state than on a company's state of incorporation. If states are really interested in encouraging domestic employment they have at their disposal criteria far more effective than the clumsy and irrational classification of local incorporation. Similarly, the state's interest in securing property tax revenue logically depends more on the assets invested in the state than on the state of incorporation of the companies that do business there. ${ }^{48}$

Discriminating against a company because it is incorporated out-ofstate is also unwarranted as a means of increasing state revenues by increasing the taxes paid on business transacted within the state. A company that changes its state of incorporation to become locally chartered will not necessarily transact more local business. In any event, to induce the company to incorporate in-state, the state would offer a lower tax burden on business that would otherwise be transacted in the state, not a higher one. Neither is the purpose of increasing state revenue at the expense of out-ofstate corporations-as opposed to the purpose of increasing state revenues generally-permissible. It is nothing more than the transfiguration of the definitionally impermissible purpose of favoring locals because they are local. ${ }^{\text {.0 }}$ "Nor," says Sunstein, "is political strength a legitimate justification." $"{ }^{\prime 1}$ It too is no different from favoring locals because they are local. ${ }^{\mathbf{5 2}}$

This is not necessarily to say that there are no conceivable purposes that would legitimately allow a state to discriminate against foreign corporations. For instance, a state might want to aid local businesses because they tend better to serve local needs. ${ }^{53}$

the State's Interest in Protecting Its Own, 23 WM. \& MARY L. REv. 173 (1981); Sunstein, supra note 42 , at $129-45$ (equal protection clause).

49. The statute found to be unconstitutional in Metropolitan Life Insurance Co. v. Ward, 470 U.S. 869 (1985), see infra text accompanying notes 54-55, allowed foreign insurance companies to reduce the tax differential between themselves and domestic insurance companies by investing an increasingly large percentage of their assets in Alabama, but did not allow them to eliminate it entirely. See AlA. CODE $\$ \S 27-4-4$ to -5 (1975). Thus, prior to the Supreme Court decision, even if a foreign insurance company invested $100 \%$ of its assets in Alabama, it was still taxed at a higher rate than domestic insurance companies. At least a portion, therefore, of the Alabama statute was not aimed at possible employment or property tax benefits to the state.

50. Note, Taxing Out-of-State Corporations, supra note 43, at 887 ; see also Western $\&$ Southern, 451 U.S. at 669 (implying that such a purpose would be illegitimate, the Court said that "it is clear that [California's] purpose is not to generate revenue at the expense of out-of-state insurers").

51. Sunstein, supra note 42 , at 134 .

52. Id.; see also Note, Taxing Out-of-State Corporations, supra note 43, at 893-95 (1982) (political process unable to protect out-of-state corporations). See generally J. ELY, DEMOcRACY AND DisTRUST (1980). But see infra note 54.

53. See, e.g., Hearings on S. 1362 Before the Subcomm. on S. 1362 of the Senate Comm. on the Judiciary, 78th Cong., 1st Sess. 16-17 (1943) (statement of Sen. Bailey) (role of domestic insurers in providing for specific local needs). This purpose too has been questioned. See Note, Regional Banking Statutes and the Equal Protection Clause, 84 Colum. L. Rev. 2025, 2034-37 (1984). The Columbia Note argues that the regional banking statutes are unconstitutional because they fail the rational basis test. That such arguments are not only possible but convincing underlines the necessity of utilizing a 
Given this analysis a court might make one of two arguments. The first is that because of the loose fit between in-state/out-of-state classifications and permissible state purposes, courts ought to be skeptical of arguments that specific state statutes using this classification are not motivated solely by a desire to favor insiders and should subject them to some form of heightened scrutiny. ${ }^{54}$ The second argument, more important for this Note, is that because discrimination against out-of-state corporations is almost never rationally based, court decisions upholding discrimination of this sort would stand on firmer ground if they offered a jurisdictional argument.

In justifying discrimination against foreign corporations, states are likely to proffer false purposes because legitimate purposes that tend to find favor with courts are not generally furthered by classifications that distinguish between in-state and out-of-state corporations. A state's actual purpose is usually to favor domestic businesses at the expense of foreign corporations. The judicial system would do well to admit that in certain narrow circumstances-when a foreign corporation is trying to enter a state and Congress has waived its commerce clause powers, or when a foreign corporation doing business in a state is attempting to expand the scope of that business-the state has the power to discriminate, rather than to approve such discrimination only after the state has jumped through the largely artificial hoops of the rational relation test.

threshold jurisdictional test to explain the Court's decision in Northeast Bancorp v. Board of Governors of the Federal Reserve System, 472 U.S. 159 (1985). See infra text accompanying notes 55-56. The Columbia Note, however, follows Western \& Southern, 451 U.S. 648, in incorrectly concluding that Paul v. Virginia, 75 U.S. (8 Wall.) 168 (1868), has been eroded by the advent of general incorporation laws. Paul v. Virginia held under the privileges and immunities and commerce clauses that states could exclude foreign corporations entirely from doing business in the state. Paul v. Virginia, 75 U.S. (8 Wall.) at 181. It does not follow that general incorporation laws, which permit persons freely to form domestic corporations, call this holding into question.

The other question addressed by the Court in Western $\mathbb{Z}$ Southern-to what extent Paul v. Virginia, based on the privileges and immunities clause, has been eroded by the passage of the equal protection clause-is the question addressed in this Note.

54. The appropriateness of heightened scrutiny does not rest on the presence of some process defect that prevents out-of-state corporations from having the same effect on the legislative process as in-state corporations. But see supra note 52. No process defect exists because the foreign corporation is by definition an outsider not meant to participate in the formation of domestic laws. See Brilmayer, Carolene, Conflicts, and the Fate of the "Inside-Outsider," 134 U. PA. L. Rev. 1291, 1326-28 (1986). Rather, heightened scrutiny would be proper because of the illegitimacy of the great majority of state purposes used to justify discrimination between in-state and out-of-state corporations.

This presumption of illegitimacy is established by an ex ante rational relation test that examines the "fit" between a discriminatory legislative classification and its purposes by examining how probable it is that the classification serves its purported goals. The effect of this ex ante examination is not to foreclose the state from invoking possibly legitimate purposes or even those that are presumptively illegitimate. Rather it imposes a heavier burden on a state attempting to justify discrimination against out-of-state corporations by requiring that, (1) those states relying on legitimate purposes bear the burden of proving that these are their true purposes (because there are so many that are not legitimate), and (2) those invoking presumptively illegitimate purposes bear the burden of proving that, in a particular case, they are legitimate (because, in general, the classification does not further them). 


\section{METROPOLITAN AND NORTHEAST BANCORP}

The efficacy of the jurisdictional approach outlined above is best demonstrated by applying it to two cases decided by the Supreme Court in 1985. In Metropolitan Life Insurance Co. $v$. Ward, ${ }^{55}$ a five-to-four majority held that encouraging the formation of new domestic insurance companies and encouraging domestic investment by foreign insurance companies were illegitimate state purposes under the Fourteenth Amendment when furthered by imposing discriminatory taxes on foreign insurance companies.

In Northeast Bancorp v. Board of Governors of the Federal Reserve System, ${ }^{58}$ with the future of regional banking at stake, ${ }^{57}$ a unanimous court upheld Massachusetts and Connecticut statutes permitting out-ofstate bank holding companies based in one of the other New England states to acquire in-state banks, but prohibiting out-of-state companies from outside the New England region from doing the same. ${ }^{58}$

In neither case was the commerce clause at issue. Congress has authorized state regulation of both the banking and insurance industries through appropriate legislation..$^{58}$ No member of the Court questioned the fact that

55. 470 U.S. 869 (1985).

56. 472 U.S. 159 (1985).

57. For a compilation of the different state statutes establishing regional banking compacts, see Comment, Regional Reciprocal Banking Laws: Constitutional, But What Next?, 14 FLA. ST. U.L. REv. 267, 288-89 nn.144-45 (1986). For a discussion of the various statutes in force prior to the decision in Northeast Bancorp, see 71 Fed. Res. Bull. 430 (1985) (statement of Paul A. Volker, Chairman, Bd. of Governors of the Fed. Res. Sys., before the Suboomm. on Financial Institutions Supervision, Regulation and Insurance of the Senate Comm. on Banking, Finance and Urban Affairs).

58. Having dissented in Metropolitan, Justice O'Connor wrote in Northeast Bancorp not only that Metropolitan had been wrongly decided, but also that the decisions in the two cases were irreconcilable. She stated:

It is not clear to me why completely barring the banks of 44 States from doing business is less discriminatory than Alabama's scheme of taxing the insurance companies from 49 States at a slightly higher rate. Nor is it clear why the Equal Protection Clause should tolerate a regional "home team" when it condemns a state "home team."

472 U.S. at 179 (O'Connor, J., concurring).

59. The McCarran-Ferguson Act, 15 U.S.C. $\S \S 1011-1015$ (1982), explicitly lifts commerce clause restraints on state regulation of insurance. See Board of Ins. v. Todd Shipyards Corp., 370 U.S. 451 (1962); Prudential Ins. Co. v. Benjamin, 328 U.S. 408, 431 (1946). This law was enacted in response to the Supreme Court's decision in United States v. South-Eastern Underwriters Association, 322 U.S. 533 (1944) (holding that insurance was "commerce" within the meaning of the commerce clause).

The Douglas Amendment to the Bank Holding Company Act, 12 U.S.C. § 1842(d) (1982), prohibits a bank holding company or bank in one state from acquiring a bank in another state, unless the acquisition "is specifically authorized by the statute laws of the State in which such bank is located, by language to that effect and not merely by implication." The Court had not previously confronted the question whether the Connecticut and Massachusetts statutes-allowing acquisitions on a regional basis only - were of the type contemplated by the Douglas Amendment. In Northeast Bancorp the Court relied on the opinion of the Federal Reserve Board and on legislative history in holding that the Douglas Amendment encompassed the regional banking statutes passed by the Connecticut and Massachusetts legislatures. See Northeast Bancorp, 472 U.S. at 168-75. 
the state statutes involved fell within the scope of that legislation. Nor were the protections of the privileges and immunities clause applicable. ${ }^{80}$ The challenges mounted in both Metropolitan and Northeast Bancorp, therefore, were necessarily based on the Constitution's guarantee of the "equal protection of the laws."

In Northeast Bancorp the Court concluded that the Massachusetts and Connecticut statutes at issue passed muster under the traditional rational basis test. "[W]ith respect to the business of banking," the Court noted, it was not writing "on a clean slate." " " $[\mathrm{B}]$ anking and related financial activities are of profound local concern," " interest in preserving "a close relationship between those in the community who need credit and those who provide credit."

In Metropolitan, the issue was whether Alabama could discriminate against insurance companies that were doing business in the state but had been incorporated outside of it. ${ }^{65}$ In Northeast Bancorp, on the other hand, Massachusetts and Connecticut excluded bank holding companies that had never been admitted into these states for banking purposes. The distinction between these positions is constitutionally significant. It is pre-

For the purposes of this Note, there is no reason to question this analysis. Nevertheless, there are commentators who disagree with the Court's result. See, e.g., Miller, Interstate Branching and the Constitution, 41 Bus. LAw. 337 (1986) (statute unconstitutional under commerce clause); Comment, Banking Law-Regional Banking Agreements and the Resurrection of Interstate Rivalries: Northeast Bancorp, Inc. v. Board of Governors of the Federal Reserve System, 11 J. CorP. L. 477, 487-90 (1986) (same); Comment, supra note 57, at 279-81 (same); id. at 273-79 (Douglas Amendment did not contemplate regional banking statutes).

60. See supra note 5 .

61. In Metropolitan, commerce clause and privileges and immunites clause claims were not even raised. These issues were clearly foreclosed by Western $\mathcal{E}^{\prime}$ Southern, 451 U.S. at 655-56. In Northeast Bancorp the commerce clause claim, but not the privileges and immunities clause claim, was heard and dismissed. Northeast Bancorp, 472 U.S. at 174-75; see also supra note 59.

62. Northeast Bancorp, 472 U.S. at 177.

63. Id. (quoting Lewis v. B.T. Inv. Managers, 447 U.S. 27, 38 (1980)).

64. Northeast Bancorp, 472 U.S. at 178. Upon concluding that the state has a legitimate interest in promoting its local banking industry, the majority had little difficulty finding that the regional banking statutes at issue in Northeast Bancorp were rationally related to furthering that interest.

65. Northeast Bancorp is distinguishable from Metropolitan in a technical sense because in Metropolitan the question of the legitimacy of preserving locally responsive institutions was not directly before the Court. In Metropolitan, the only issue on appeal was, by stipulation of the parties, the legitimacy of two state purposes: encouraging the formation of domestic insurance companies and encouraging capital investment by foreign insurance companies. Metropolitan, 470 U.S. at 873-74. For several reasons, this is not an adequate explanation of the fact that the Court struck down as unconstitutional one attempt to discriminate against out-of-state corporations and upheld another. First, Justice Rehnquist distinguished Northeast Bancorp from Metropolitan without direct reference to the technical posture of the latter case. Second, the majority in Metropolitan unequivocally held that the "promotion of domestic business by discriminating against nonresident competitors is not a legitimate state purpose." Id. at 882.

The purpose found to be legitimate in Northeast Bancorp was not very different. Indeed, Justice O'Connor contended that the "interest in preserving local institutions responsive to local concerns was a cornerstone in Alabama's defense of its insurance tax." Northeast Bancorp, 472 U.S. at 179-80 (O'Connor, J., concurring). For an argument that the statutes at issue in Northeast Bancorp fail the rational basis test, see Comment, supra note 57 , at 284-88. 
cisely the distinction between an entity that is inside and one that is outside the state's jurisdiction for purposes of the equal protection clause. Within the framework presented in this Note, Metropolitan was doing business in Alabama, was subject to the jurisdiction of its courts and legislature, and was therefore "within its jurisdiction" for purposes of the equal protection clause. Alabama's discriminatory tax scheme was held unconstitutional because the Court found that the scheme lacked a rational basis. The bank holding companies in Northeast Bancorp on the other hand, although arguably subject to the jurisdiction of the Massachusetts and Connecticut state courts, were not doing business in those states, ${ }^{68}$ and, moreover, were attempting to enter those states without their consent. Under these circumstances and for these purposes, they were outside the jurisdiction of Massachusetts and Connecticut and unable, therefore, to invoke the equal protection of their laws. ${ }^{67}$

66. Although "doing business" after International Shoe is no longer the touchstone of jurisdictional analysis, this Note argues that it still plays an important role in determining the extent of the state's jurisdiction for purposes of the equal protection clause. See supra text accompanying notes 19-23.

67. There are several decisions which appear to run counter to the argument presented in this Note. In Prudential Insurance Co. v. Benjamin, 328 U.S. 408 (1946), the Supreme Court faced a fact situation nearly identical to that presented in Metropolitan but reached a different result. It upheld a South Carolina statute imposing an additional tax on foreign corporations as a condition of doing business in the state. Justice O'Connor has cited Benjamin for the proposition that 'the McCarranFerguson Act's effect was 'clearly to sustain the exaction and that this can be done without violating any constitutional provision." "Metropolitan, 470 U.S. at 890 (O'Connor, J., dissenting) (quoting Benjamin, 328 U.S. at 427) (emphasis of O'Connor, J.). Benjamin, however, is a red herring. Prudential did not argue or even present an equal protection claim. The controlling issue was a claim under the commerce clause: "Prudential has not urged grounds founded upon other constitutional provisions than the commerce clause, except in relation to the McCarran Act . . . Benjamin, 328 U.S. at 437. And the only arguments made in this latter respect were based on (1) the due process clause of the Fifth Amendment, (2) Article I, \& 8, requiring uniform excise taxes, (3) Article I, $\S 1$, giving Congress the sole power to legislate, and (4) the Tenth Amendment.

Within the framework developed in this Note, the most difficult case to defend is Blake v. McClung, 172 U.S. 239 (1898); see supra note 12. Logically, the discussion should begin by referring to a later case: In Kentucky Finance Corp. v. Paramount Auto Exchange, 262 U.S. 544 (1923), the Court invalidated a statute that imposed more onerous burdens in the taking of and submission to depositions on out-of-state corporations than in-state corporations. The Court held that a foreign corporation that goes into a state where it has no assets or agents to repossess property that had been unlawfully taken from it is a person within the "jurisdiction" of that state "for all the purposes of that undertaking." Id. at 550. Justices Brandeis and Holmes argued that such an interpretation "would seem to require the Court to overrule Blake v. McClung." Id. at 552 (Brandeis \& Holmes, JJ., dissenting). And it is hard not to agree.

Blake decided that a foreign corporation in such circumstances was outside the state's jurisdiction for purposes of the equal protection clause. Under the analysis developed in this Note, however, it would still be entitled to equal protection to the extent of its legitimate dealings in the state. Blake refused to extend the equal protection clause to cover those transactions. If Blake is good law and Kentucky Finance was wrongly decided, then a foreign corporation in the courts of a state in which it does not regularly conduct business must litigate without the benefit of equal protection. The Court's equal protection analysis, of course, is unaffected by the fact that this corporation might have cognizable claims under either the due process clause or the full faith and credit clause.

The better argument maintains that the legitimate presence of the plaintiff's automobile, for example, within the territorial jurisdiction of the state is enough to entitle it to the equal protection of the laws "for all the purposes of that undertaking." The plaintiff foreign corporation is not attempting to 
This interpretation of the phrase "within its jurisdiction" seems not only useful but necessary in explaining the different decisions in these two cases. ${ }^{68}$ Justice O'Connor's question, it should be remembered, remains unresolved: both cases arguably concern the legitimacy of local favoritism, and it is indeed "unclear" under rational relation scrutiny why "the Equal Protection Clause should tolerate a regional 'home team' when it condemns a state "home team." "68

Ostensibly, it is possible to justify the decisions in these cases by reference to the rational basis test. However, the strained nature of the Court's opinions and the difficulty of reconciling the two decisions attest that this is no easy feat. The rational basis test relies on finding in each case a rational distinction between the entities the state is treating differently. In Northeast Bancorp, as in Metropolitan, there just does not seem to be much of a distinction.

The jurisdictional test, on the other hand, concludes that equal protection in a given case is either applicable or it is not. The Court, by making a jurisdictional argument can avoid the difficult if not impossible task of showing that there was a legitimate state interest in, and a rational basis for, preferring the corporations of one state over those of another. ${ }^{70}$

do business in the state or to expand an existing business there; its claim arises directly out of a legitimate contact with the state. The fact that the Blake Court did not make this distinction may be best understood as a throwback to a time when territorial and personal jurisdictional concerns were more closely entwined. The Court may have been unable to conceive that the corporation involved was not within the state's territory and yet was still, for purposes of the equal protection clause, "within its jurisdiction."

68. This interpretation is also consistent with the most important predecessor to Northeast Bancorp and Metropolitan: Western \& Southern Life Insurance Co. v. Board of Equalization, 451 U.S. 648 (1981). Western \& Southern rejected the argument accepted in Lincoln National Life Insurance Co. v. Read, 325 U.S. 673 (1945), "that a State may discriminate against foreign corporations by admitting them under more onerous conditions than it exacts from domestic companies . . . "." Western $E^{2}$ Southern, 451 U.S. at 665 (quoting Lincoln, 325 U.S. at 677) (emphasis added). The Court did not, however, reject the notion that a state could exclude a foreign corporation entircly. It explicitly reserved this question: "We consider it now established, whatever the extent of a State's authority to exclude foreign corporations from doing business within its boundaries, that authority does not justify imposition of more onerous taxes . . . on foreign corporations . . . unless the discrimination . . . bears a rational relation to a legitimate state purpose." Id. at 667-68 (emphasis added).

69. Northeast Bancorp, 472 U.S. at 179 (O'Connor, J., concurring).

70. It was argued earlier that the concerns of the jurisdictional test-even if it is not directly invoked-can often be translated into a form of rational relation analysis. See supra text accompanying notes 34-38. This translation is possible when the complainant is outside the jurisdiction of the state and the class treated differently is inside it. In such a case, the rational basis and jurisdictional tests generate similar results. It is not as easy with a case like Northeast Bancorp. There, both the class discriminated against and the class from which it is distinguished are outside the state's jurisdiction. The "concerns" of the jurisdictional element-if they speak at all-say only that because both classes are outside the reach of the state it may be less careful in distinguishing between them. The jurisdictional element, in easy cases, has at least clarifying power. Cases like Northeast Bancorp seem almost impossible to decide without it. 


\section{Jurisdiction and Equal Protection}

\section{ConCLusion}

It is almost never rational under the equal protection clause for a state to discriminate against foreign corporations doing business in the state, or to discriminate among out-of-state corporations. The Court's reasoning in Northeast Bancorp-though not its result-relying as it does on the application of rational relation analysis, is for this reason without adequate foundation. Although there are times when a state may legitimately discriminate against foreign corporations, the universe of such situations is small and well-bounded. ${ }^{71}$

A state may discriminate against a foreign corporation when that corporation is outside the state's jurisdiction. A state may also discriminate against a foreign corporation that is attempting to gain entry to the state, or to expand the scope of its business, by invoking the equal protection of that state's laws. At all other times the state has a duty to provide equal protection to foreign corporations. And once that clause applies, the state will generally be unable to find any rational justification for further discrimination. In application, the jurisdictional test is certainly more rigid than the rational basis test, but it also has more meaningful content. Moreover, the Constitution-specifically, the jurisdictional provision to which this Note has given substance-requires it.

71. That an entity is outside the jurisdiction of a state does not mean that the state may in general subject it to discrimination. It merely means that if that entity has a claim, it is under the commerce clause, or, if a natural person, under the privileges and immunities clause. This is why affirmative deference by Congress to state regulation is often dispositive of such complaints. It is dispositive when there is no equal protection claim, but only a claim under the commerce clause. It does not, however, dispose of the equal protection claim, if there is one.

Thus Justice O'Connor is confused when she thinks it pertinent with respect to Metropolitan that "the local nature of insurance is firmly ensconced in federal law." Northeast Bancorp, 472 U.S. at 179 (O'Connor, J., concurring). The McCarran-Ferguson Act would be dispositive of Metropolitan only if there were no equal protection claim-that is, if Metropolitan were outside Alabama's jurisdiction. If that were the case, Metropolitan's remaining claim would be under the commerce clause, and congressional action under that clause would be determinative. 